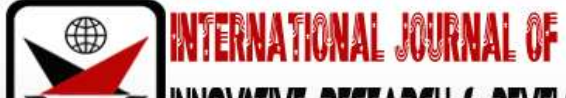

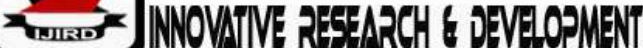

ISSN 2278-0211 (Online)

\section{Policy Implementation of Bela Beli Progo Kulons in Regional Rice Program}

Ferid Nugroho
Postgraduate Student, Department of Public Administration
Domestic Government Instituts Jakarta, Indonesia
Ermaya Suradinata
Promoter, Department of Public Administration
Domestic Government Instituts Jakarta, Indonesia
Johanes Basuki
Co-Promotor, Department of State Administration
Lembaga Administrasi Negara Republic of Indonesia, Indonesia
Suhajar Diantoro
Co-Promoter, Department of National Border Management Agency Republic of Indonesia,
Ministry of Internal Affairs Republic of Indonesia, Indonesia
Ahmad Jazuli
Lecturer, Department of Finance, Tazkia Institut of Economic Science Bogor, Indonesia

\section{Abstract:}

Policy is a guideline for actors whether private sector officials or government agencies in carrying out a particular field of activity. The policies carried out by the government both the central government and regional governments are often called the policies of the state. State policy is more an action that leads to a goal than as a random or accidental behavior or action. State policy in the present generally is not an accidental act but a planned action.

Policy consists essentially of interrelated and patterned actions that lead to specific goals undertaken by government officials and do not constitute decisions of their own. Policy has to do with what the government actually does in certain fields.

State policy may be positive or negative. In a positive form state policy may include various forms of government action intended to influence a particular problem, while in the form of a negative decision by government officials not to take any action on an issue where government intervention is actually needed.

In other words, the government can adopt a very liberal policy or wash hands completely, either in whole or in part of life sectors. Of course, the absence of government interference will have a certain impact on all members of the community or a portion of the community members concerned.

Policy regarding regional rice; This policy is certainly very useful, because to get quality rice that is received by poor households do not need to wait from Bulog first, because it can be provided by farmer groups and farmers' groups in Kulon Progo Regency. With the availability of rice originating from among his own circles this has made money turnover in the Kulon Progo Regency area.

The impact of rice farmers will get certainty that the rice produced will be bought by the market and the price is in accordance with what is desired by farmers. This makes farmers have a certain income related to their efforts to grow rice. With certain income, of course they will be able to use the income for the purpose of improving their standard of living.

Keywords: implementation of policies, regional programs, welfare improvement

\section{Introduction}

Every government strives to always prosper every citizen, so that they are free from the shackles of poverty. In making a decision on policy, the government usually sticks to the situation and condition of the local community so that it is not obstructed in deciding a policy. In addition, the policies that are decided can be of direct benefit to all people as citizens of an area.

In making policy Charles Lindblom in Solihin Abdul Wahab (1997: 16) said that state policy making is essentially an "extremly complex, analytical and political process to which there is no beginning or end, and the boundaries of which 
are most uncertain. Somehow a ... complex set of forces that we call policy making all taken together produces effects called policies

Amital Etzioni in Solihin Abdul Wahab (1997: 17) explains that it is through the decision-making process that community commitments are translated by actors (politics) into more specific commitments into concrete actions and goals.

While Chief J.O. Udoji in Solihin Abdul Wahab (1997: 17) formulates in detail the making of state policy as "the whole process of defining and defining probles, formulating possible solutions into political demands, ch into the political systems, canelling those demands into the political systems, seeking sanctions. or legitimacy, monitoring and review (feed back) ".

\section{Discussion}

The Declaration of Bela Beli Kulon Progo is implemented by the Agriculture and Food Crops Office of Kulon Progo Regency with several programs, namely: Rice for the State Civil Apparatus. The rationale is that nearly 60\% of the Kulon Progo Regency Regional Budgeting and Expenditure Budget is used for the salaries of the State Civil Apparatus. So, this is a promising rice market potential. Then the Regent of Kulon Progo made a policy that the State Civil Apparatus was deemed necessary to have concern for farmers to become a potential rice market. The State Civil Apparatus is called upon to be able to Buy rice from the distributed by the Farmers Group Association to the Regional Apparatus Work Unit in Kulon Progo Regency every month for $10 \mathrm{~kg}$ of Gapoktan brand rice. This State Civil Apparatus Rice has been started since 2013. The results of this policy can be seen from the table of realization of the State Civil Apparatus rice and Rupiah Value in circulation as follows:

\begin{tabular}{|c|c|c|c|c|c|c|}
\hline & 2012 & 2013 & 2014 & 2015 & 2016 & 2017 \\
\hline $\begin{array}{c}\text { Beras Aparat } \\
\text { Sipil Negara }\end{array}$ & 109,2 & 157,1 & 156,7 & 160,7 & 160,5 & 160,8 \\
\hline Nilai edar & 930,75 & $1,335,35$ & $1,448,65$ & $1,526,65$ & $1,685,25$ & $1,688,40$ \\
\hline
\end{tabular}

Table 1: Realization of State Civil Servants Rice and Rupiah Value Outstanding in 2012 - 2017 Kulon Progo Regency in Tons and Million Rupiahs Source: Department Of Agriculture and Food Crops Kulon Progo 2018

The Department of Agriculture and Food Crops was also affected by the policy of Bela Beli Kulon Progo related to the change from poor rice to regional rice. The concept of poor rice was that Bulog provided rice supplies in Bulog warehouses around the Kulon Progo Regency to recipient households. But people who receive poor rice often complain asking why rice received from Bullog is often yellow, musty smell, and there are curses.

Starting from that condition the Department of Agriculture and Food Crops was given the task of self-sufficiency in rice to meet the needs of the poor rice program from the central government to be transferred to regional rice. The effort made by the Kulon Progo Regency Government to fulfill rice needs independently succeeded with the signing of an agreement between the Kulon Progo Regency Government and the Yogyakarta Regional Division Bulog whose contents outline were, the Kulon Progo Regency Government that provided rice for poor Ganges houses while Bulog provided money to buy the rice.

So the Department of Agriculture and Food Crops of Kulon Progo Regency together with farmer groups and the Farmer Groups Association provide rice for the needs of Raskin recipient households on a regular basis. By way of intensification and extensification of agricultural land, until now Kulon Progo Regency has become a rice surplus area, so that it can be sold to other areas in the vicinity.

In addition to the needs of poor households, the Kulon Progo Regency Government also made an appeal for the State Civil Apparatus within the Kulon Progo Regency Government to buy rice from farmers, farmer groups or farmer groups combined, provided by the Agriculture and Food Crops Office to be distributed to the all regional work units throughout the Kulon Progo Regency.

With the grain yield reaching 120,000 tons if it is made into rice it will be around 85,000 tons of rice so there is an excess of rice around 35,000 - 40,000 tons. This excess is expected by the Regent to be distributed to the State Civil Apparatus, with the implementation of a circular that every State Civil Apparatus in the Kulon Progo Regency is obliged to buy rice from the Farmers Group Association around 5-10 kg a month. So that the excess rice can be absorbed by all levels of society in Kulon Progo Regency.

Thus rice products produced by farmers in Kulon Progo Regency can be sold so that farmers' income will increase. Rice produced by farmers is distributed to all villages in Kulon Progo Regency with 87 villages and 1 village. So that the people of Kulon Progo Regency can easily get rice from their own farmers. Another benefit is breaking the rice distribution chain, so that the price of rice becomes more affordable among the people, so the price is in line with the Highest Retail Price. In addition, the large market is clear, namely the State Civil Apparatus, People's Owned Stores (ToMiRa) and the community in the Kulon Progo Regency area.

The Regent said natural resources in Kulon Progo were abundant. Likewise, the agriculture and plantation sectors both in the southern (coastal) and northern regions of the Menoreh mountains. But in terms of labor, there are still many Kulon Progo residents who make a living in the city of Yogyakarta and surrounding areas. In mid-2013, he ran the Bela Beli Kulon Progo program in agriculture. The Regency Government facilitates the formation of a Joint Farmer Group. They are also trained to attend various trainings. Farmers are invited to not only sell crops in the form of grain, but process and 
package it into rice. They are also facilitated by grinding machines and capital assistance as well as management or management training.

The Farmers Group Association is trained to package it properly according to the standard. But this is also not an easy case. At first many farmers were not used to it. They used to sell it immediately, but slowly they wanted to," said the man from the obstetrician's background. After that when the rice was on the market and could be absorbed, Hasto required the State Civil Apparatus within the Kulon Progo Regency Government to buy rice from farmers. A total of 8 thousand State Civil Apparatuses in Kulon Progo buy a minimum of 10 kilograms every month. "This pro-rice movement was successful, although there were those who agreed and did not,

The Bulog of the Yogyakarta Special Region Division was also affected by its discretion at the Bela Beli policy. So far, the National Logistics Agency (Bulog) is supplying rice which is imported rice to be distributed to the beneficiaries of poor rice, now the supply has been replaced because all the rice needs for the poor beneficiaries have been fulfilled by local farmers through the regional rice program. Not only able to meet the needs of the poor rice program, farmers who are members of the farmer groups and farmer groups combined are able to sell their rice outside the Kulon Progo Regency because of a surplus of production

Along with the program, Regent Hasto Wardoyo also succeeded in establishing cooperation with Bulog. He asked Bulog to buy rice for poor rice from local farmers or the Association of Farmers Groups. As many as seven of the 12 Joint Farmers Groups have collaborated with Bulog to supply poor rice. In 2014 it supplied 1,900 tons and in 2015 it had increased more than that amount. The regional or regional rice program, according to Hasto, has been submitted to President Jokowi and received a positive response. While from the farmer's side, income also increases. This combined Farmer Farmers' rice production with good packaging has also been sold at minimarkets in Kulon Progo.

"Our goal is to take over 7 thousand tons. The rice surplus here (KulonoProgo-ed) we hope to be able to meet the needs of rice in other places such as the city of Yogyakarta where there are no more paddy fields," he explained. Kulon Progo also produces its own rice. His background because of the poor weight supplied to the region turned out to be rice from Vietnam and India. I am hurt. Why is the source of poor rice not from Kulon Progo farmers? Finally, we signed an MoU with Bulog on 30 December 2013, no more foreign rice was brought in. Just bring money and buy farmer rice. Finally, rice was bought from farming, and its name is not poor rice, but regional rice (regional rice). Then we require the State Civil Apparatus to Buy $10 \mathrm{~kg}$ of rice a month. Every year the State Civil Apparatus buys more than 160 thousand kg of rice. In Kulon Progo there are 8,000 State Civil Apparatuses.

At present every time Bulog goes to Kulon Progo to bring Rp 4.5 billion to buy farmers' rice. The annual allocation of rice is more than 8,000 tons with an average monthly rate of 645 tons. I seduced the head of Bulog for almost a year. We guarantee the availability of rice and warehouses in every Farmers Group Association. Then the availability of processing facilities in each Farmers Group Association, and institutional strengthening of Farmers Groups and Farmers Groups

Then we redesigned poor rice to regional rice by making the Farmers 'Association a provider and distributor of poor rice, then the quality assurance operational costs are managed by the Farmers' Association, the region is authorized to verify the target of poor Rice, and the amount of allocation per Target Household is adjusted to the number of Target Household members. The concept of this regional rice system has been made. So, if the Regent changes, the program will continue. One of them is the purchase of rice from agriculture increases regional income, as well as the sale of rice. If this program is stopped, regional income will decrease.

Eradicating people from poverty is an ideal that is difficult to realize. Various attempts were made by each regional head and head of state at the same time. In addition to prayer and hard work, that is what the Regent of Kulon Progo, Hasto Wardoyo, did. Kulon Progo, which was a disadvantaged area, is now known as a highly developed Regency in poverty alleviation. Through the "Bela and Beli Kulon Progo" movement, community members move out of poverty with their own strength.

Statistical data shows the poverty rate in 2013 (22.54\%) in 2014 became $16.74 \%$ when Hasto Wardoyo took office in the first period. Kulon Progo farmers no longer sell their rice outside the region but they sell it for their own area. "I oblige the State Civil Apparatus to buy $10 \mathrm{~kg} /$ month of farmers' rice. Hasto Wardoyo hopes that public money revolves around the Kulon Progo area not in a neighboring country.

The rice in the National Logistics Agency (Bulog) is also the Kulon Progo people's rice bought from the Farmers Group Association under the guidance of the Agriculture Office. Kulon Progo rice farmers are able to meet the needs of the community. The enthusiasm of the Kulon Progo community for the applied policies can improve the welfare of farmers. One of them is Yatmin, a farmer from the Glagah area who has succeeded in sending his children to university only by farming in the fields.

"Thank God, I am a villager whose job is only farming, my child can go to university. I used to be afraid of sending my children to university because of the high costs, but because the Regent Hasto Wardoyo applied the State Civil Apparatus policy. maximum results until finally my rice is sold and can be used for tuition. " Growing farmers (in the interview)

Substituting Raskin (Poor Rice) to Rasda (Regional Rice). This replacement is due to the condition of the rice received by the beneficiary's family in conditions that are often found to be dull in color, most have been crushed, then they have musty smell and many rice lice. In addition, rice in Kulon Progo Regency experienced a surplus.

The policy of replacing poor rice into regional rice in Kulon Progo Regency is an effort to answer the problem of poor rice in the field, especially the condition of rice which when received by beneficiary families is in poor condition or can be said to be poor, the amount is inadequate or not according to the needs and the issue of the distribution time is rather long. In addition, local rice in Kulon Progo Regency is sufficient if used to distribute regional rice as a substitute for poor rice which is a program of the Central Government. 
With the existence of regional rice produced by farmers in Kulon Progo Regency and with an adequate amount, the Kulon Progo Regency Government can realize new baras that are of interest to beneficiary families because the quality of rice received is better than the poor rice received previously. Besides transportation for regional rice distribution becomes cheaper, because it does not have to go through the distribution channels that have been determined by the Government in this case the Yogyakarta Special Region Regional Bulog.

Realization of regional rice is quite large and with the circulation of a large rupiah value can also help alleviate the poverty of farmers who are members of the farmer groups or who have not been incorporated into farmer groups. With the certainty of the rice market, which is from the buyer who is a State Civil Apparatus in the Kulon Progo Regency environment, this will spur economic growth in the countryside. Because the farmer can quickly get the produce from the rice, he sells to the local State Civil Apparatus. From this condition, the welfare of the farming community in Kulon Progo Regency increased by itself.

The activity of replacing poor rice into Regional Rice is an embodiment of Law No. 18 of 2012 concerning food, which mandates that in realizing food affordability, the Government and regional governments carry out policies in the field of food assistance. This policy was taken by the Regent of Kulon Progo in an effort to facilitate food affordability for its citizens.

After implementing the policy of replacing poor rice into regional rice, several benefits from regional rice can be felt, including:

- Improve the quality of rice received by beneficiary families

- Shortening the distribution chain from before

- Increase farmers' income, so that they can improve the welfare of farmers

- Empowering farmer groups and farmer groups combined in the Kulon Progo Regency area

- Moving the regional economy, because money circulation only occurs within the Kulon Progo Regency

- Contribute to a reduction in poverty in the Kulon Progo Regency.

The replacement of poor rice from the central government to regional rice in Kulon Progo Regency was officially begun after the Memory of Understanding between the Bulog Division of the Special Region of Yogyakarta and the Kulon Progo Regency Government on December 30, 2013, with numbers 501/7496 and MOU-01/12000 / XII / 2013. This MoU deals with the procurement of rice from the Kulon Progo Regency Poor Rice Program from the Kulon Progo farmers' production through the Association of Farmers Groups. The MoU was followed up with an MoU with the ability to procure poor rice between the Joint Farmers Group and the Head of the Yogyakarta Special Region Regional Division on 27 January 2014. The collaboration was carried out on several considerations taken by the Kulon Progo Regency Government, including:

- Availability of rice warehouses in every Farmers Group Association in Kulon Progo Regency

- Availability of processing facilities from rice to rice, which includes harvested rice dryers, tester tools and others

- Availability of rice packaging devices in the bag

- And institutional strengthening of farmer groups and farmer groups managerially and technically.

A glimpse of the realization of regional rice and the value of the rupiah circulating from 2014 to 2017, can be seen in the table belo

\begin{tabular}{|c|c|c|c|c|}
\hline & 2014 & 2015 & 2016 & 2017 \\
\hline Beras daerah & 1.995 & 4.276 & 4.950 & 4.680 \\
\hline Nilai Edar Rupiah & 13.167 & 31.214 .8 & 36.135 & 38.884 \\
\hline
\end{tabular}

Source: Department of Agriculture and Food Crops, Kulon Progo Regency 2018

The distribution of regional rice to beneficiary families has also changed significantly. When Bulog distributes it to beneficiary families, to get to the recipient it must go through formal distribution channels, starting from the relevant Dinas, then through the sub-district government, then through the kelurahan or village government, through the dukuh head and so on. Now the scheme has been abandoned, and uses a simpler schema. The work scheme for regional distribution is as follow

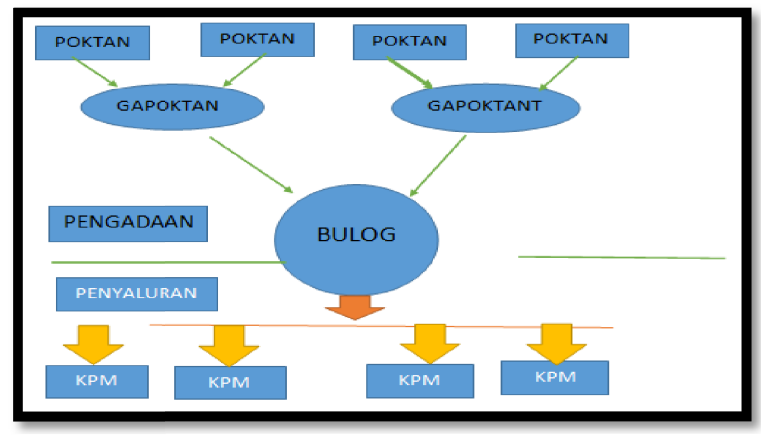

Figure 1

Source: Aariculture and Fond Crons Office of Kulon Proan Reaency 


\section{Conclusions}

The implementation of the regional rice policy which is the implementation of the Kulon Progo purchase and purchase policy, which is related to the spirit of Madh Mantep ManganEPe Foode dhewe turns out:

- Can increase regional rice production produced by farmers, farmer groups or farmer groups combined

- Can increase farmers' income, because the rice market is available so that the sale is guaranteed

- Can improve the welfare of farmers in general.

\section{References}

i. Hoogerweri, A. (1983). Public Administration. Jakarta: Erlangga.

ii. Sugiyono (2017). Qualitative Research Methods. Bandung: Alfabeta.

iii. Sugiyono (2017). Policy Research Methods: Quantitative, Qualitative Approaches, R\&D Combinations and Evaluation Research. Bandung: Alfa Beta.

iv. Udoji (1981). The African Public Policy in Africac Servant: As. Adis Abeba

v. Wahab, S. A. (1997). Policy Analysis: From Formulation to Implementation of State Policy. Jakarta: Earth Literacy. 